今日，化学工業の発展に伴って，これまで発がん性が あるといわれていた芳香族アミン類以外に, 新しいアミ ンで危险性の考えられるものもでてくる。化学工業の上 で十分その使用価值もあって，しかも発がん性のないも のをつくりだすことは，職業がん䂆防上きわめて重要で ある。そこで医学研究者と化学技術者との協力によっ て，この点に関してどのよらにすれば仿に貢献しうる か，负のためには発がんと代謝に関する基礎的研究がい が重要な関連があるか，具体的なの $2 ， 3$ 例をあげて 話したい。

\section{5. 職業性膀胱がん対策}

石津澄子（東女医大衛）

芳香族アミンによる膀胱がんが染料工業の職業病とし て注目されるよらになったのはかなり以前からであった が，日本の染料工業で生産管理，技術管理，健康管理な ぞ各方面からの対策が真剣に討議され，実施されるよう になったのはつい数年前からである。

この数年間に関係企業が実施した対策はまず最も問題 となる $\beta$-ナフチルアミン,ベンジジンの製造に関するも のであった。

すなわら，大企業のメーカーは $\beta$-ナフチルアミンの 製造を一斉に中止し，ベンジジンは施設の完備した密閉 装置でのみ製造するようにし，このため， 3 社がつぎつ ぎにプラントを新設した。

しかもベンジンの取扱いはすべてスラリ一形態でのみ 扱うようにしたため，わずかの発塺もほとんど完全に防 止されるよらになった。

一方，中小企業ではメーカ一の集積地区で企業組合の 強力な支援により，2社の中小メ一カーがベンジジンの 製造を中正，新設の一社で集中生産するという対策が成 功した。

この生産管理対策によって，少なくとも，從来のよう に施設の不完全な生産現場で発がん物質へ暴露活染され るといら危険はいちじるしく減少したのである。

もちろん，現在なお， $\beta$ ーナフチルアミンの製造を継続 している中小一社と中小企業の集積地区でヘシンジジンの 集中生産を行なっている 1 社については作業者への暴霹 污染の有無を敩密にチェックする必要があり,このため, 環境気中, 排水，作業者の尿中より $\beta$-ナフチルアミン， ベンジジンの痕跡でも検出しえないか，また，これら化 合物の代謝産物が検出しえないかを検討中である。

一方, 現在, ベンジジン， $\beta$-ナフチルアミンを取扱って
いる作業者は勿論, 過去に暴露されていた作業者につい ても健康管理を長年月継続していかなければならず，こ のため, 数年前より尿沈渣パパニコラ法が健康管理術式 として採用されるようになった。現在，大企業において は 1 社に 1 名づつ専任の技術者が配置され，中小企業集 積地区では社内にパパニコラセンターを設置, 専任の技 術者が各社作業者の尿検查を定期的に実施している。

この健康管理対策の強力な実施によって，ここ数年 来，膀胱腫演を早期に発見し，早期に治潦することが可 能となり，従来のように不幸な転帰をとる患者はいちじ るしく減少した。

したがって, 現在までのところ,ベンジジンの大小メー カに関するかぎり，第一段階の対策は終了したと思われ るが第二段階としてはベンジジン， $\beta$ ナフチルアミンの ユーザーに対する対策とその他の発がん物質に関する問 題である。その一つとして昨年来, 話題となったゴム老防 剂に使用される $\alpha$-ナフチルアミンがあり，メーカー， ユーザーについて，環境調查，健康調查が実施された。 この結果によって,メ一カーの生産現場の施設改善や $\alpha$-ナフチルアミン中の $\beta$-ナフチルアミン含有量（1\% 以下にする）規制が指令されるよらになった。

しかし，昨年12月，英国に䋆いて発命された発がん物 質規則中に計上されている禁止物質， $\beta$-ナフチルアミ

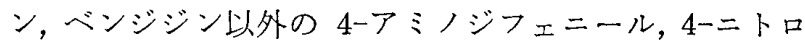
ジフェニールについては日本に和いてはまだ問題として とりあげられていない。

さらに，同上英国の法規に規制物質として計上された オルトトリジン，ダイアニシジン，ジクロルベンジン， オーラミン，マジェンタなどについても同様である。

したがって，現在の日本に括ける職業性膀脂がえ対策 はようやく, 初期の段階をお光, 次期段階にさしかか心 ているのが実状であろらと思われる。

\section{6. 発がん物血の定量法}

松下秀鶴（労衛研）

從来，発がん性物質の分析は煩雑であるばかりでなく 多大の時間と労力を要するものとされていた。そのため 発がん性物質の分析をためらら風潮も一部に見らけられ ることもあった。しかし, 現在では発がん性物質の分析 法は長足の進歩をしめし, 簡易, 迅速, 精密化され, わ ずかな練習により容易に諸種の発がん性物質を分析する ことが誰にでもできるようになった。しかも分析技術の 発達は作業環境管理のための特定発がえ物質迅速簡易分 